\title{
INCIDENCE OF PREDACIOUS ACTINEDID MITES ASSOCIATED WITH CERTAIN SOILS OF SOME FIELD CROPS IN DIFFERENT LOCATIONS OF EGYPT
}

\author{
ABDEL-RAHMAN, AMINA M. ${ }^{1}$, A. M. MOSTAFA ${ }^{2}$, A. A. YOUNES ${ }^{1}$, \\ E.M.A. YASSIN ${ }^{2}$ and RANIA H. SABER ${ }^{2}$ \\ 1- Entomology Department, Faculty of Science, Cairo University, Giza, Egypt. \\ 2- Plant Protection Research Institute, ARC, Dokki, Giza, Egypt.
}

(Manuscript received 7 December 2014)

\begin{abstract}
$\mathrm{T}$ he present study was directed towards the habitat of various predaceous actinedid (Prostigmata) mites associated with different soil field crops. Samples collected monthly from maize, cotton and soybean as summer field crops and faba bean, wheat, clover and onion as winter field ones. Incidence study conducted during the seasons of (2012/2013 and 2013/2014) revealed the occurrence of 33 different prostigmatid mite species in 9 families under 18 genera. These are Euopodidae (2 species), Erynetidae (1 species), Tydeidae (3 species), Bdellidae ( 2 species), Cunaxidae (9 species), Raphignathidae (3 species), Cheyletidae (11 species and one species for each Anystidae and Trombididae.The dominant families were Cheyletidae and Cunaxidae with the dominant species Cheletonella caucasica (Volgin), Cheyletus malaccensis Oudemans, C. eruditus (Shrank) (Cheyletidae) and Neocunaxoides andrei (Baker and Hoffman) (Cunaxidae) and Eupodes aegyptiacus Abou Awad and El-Bagoury (Euopodidae).The winter field crops were represented by 26 mite species and faba bean harbored the highest number (10 species), while, the summer field crops recorded 31 mite species of which maize soil harbored the high number (18 species). The most abundant mites were Cunaxa capreolus Berlese and C. setirostris (Family Cunaxidae) associated with 3 and 4 soil field crops, respectively and the cheyletid mites, $C$. eruditus and $C$. malaccensis which associated with four diferent soil field crops, respectively.
\end{abstract}

\section{INTRODUCTION}

Members of the subclass Acari are the largest group of invertebrates, and have large economic importance. More than 60,000 species of mites have been described from various regions of the world, the number of undiscribed species is estimated to exceed 600,000 (Evans, 1992), and the majority of such undiscribed species are expected to live in tropical regions. Actinedida and Gamasida represent the major group of soil mites which found in many soil habitats (Wallwork, 1976, Mostafa, 1980 and Convey et al., 2000). The Actinedid mites (suborder Prostigmata) represent the major group of soil mites which found in many soil habitats (Convey et al., 2000). Although the Acarina communities of Egyptian soil have not been widely studied, some information is available on the prostigmatid mites' fauna. A side from their feeding injury, some mite 
species have been found to transmit plant viruses. Many mites are predaceous on other pest and some species have been used in biological control programme.The majority of these species appear to be predators associated with small and immature stages of insects, mites, and nematodes in the soil surface (Wallwork, 1976).The present work aims to throw some light upon the incidence of some predaceous actinedid mites in different soils under some winter and summer field crops in five Governorates..

\section{MATERIALS AND METHODS}

\section{1- Survey and distribution of soil mites:}

For survey studies, soil samples of about $500 \mathrm{gm}$ were collected all over the season throughout the two successive seasons 2012/2013 and 2013/2014 from different field crops such as broad bean, Ficia faba L. and onion, (Allium cepa L.), wheat, (Triticum aestivum $\mathrm{L}$ ). and clover, (Trifolium alexandrinum $\mathrm{L}$ ). as winter crops and cotton, (Gossypium barbadense L.), maize,( Zea mays L.) and soybean (Glycine max L.) Merr) as summer crops in different regions of Egypt (Qaluobia, Giza, Menoufia, Giza and Beni Suief Governorates).Samples were freshly and singly transferred to the laboratory for mite collection in cellophane page in the same collection day. Mites extraction was carried out using modified Berlese funnels according to Krantz and Walter (2009). The extracted mites were mounted in Hoyer's medium on clean glass slides, examined microscopically then identified according to Griffiths, 1960, Summers and Price, 1970, Hughes, 1976, Zaher, 1986, Volgin, 1989 and Krantz and Walter 2009.

\section{RESULTS AND DISCUSSION}

\section{Mites' diversity and species composition of predacious actinedid soil mites:}

Incidence study reveals that the occurrence of predacious prostigmatid mites inhabiting different soil under field crops (broad bean, onion, wheat, clover, cotton, maize and soybean) during 2012/2013 and 2013/2014 sesons. As shown in Table (1) data indicated that there were 33 different mite species belong to 9 families and 18 genera were recorded as follows: Both Anystidae and Trombididae families recorded one mite species. There are two species for family Euopodidae while one species was recorded for family Erynetidae. In addition, there were three, two, nine, three and eleven species for Tydeidae, Bdellidae, Cunaxidae, Raphignathidae and Cheyletidae families, respectively. Also, obtained results cleared that cheyletid and cunaxid mites were dominant, whereas the predatory mites Cheletonella caucasica (Volgin), Cheyletus malaccensis Oudemans (Cheyletidae) and Neocunaxoides andrei (Baker and Hoffman) (Cunaxidae) and Eupodes aegyptiacus Abou Awad and El-Bagoury (Euopodidae) where dominant in the numbers. 


\section{Family: Eupodidae Koch}

Two eupodid mite species were recorded: Eupodes aegyptiacus Abou Awad and El-Bagoury and E. niloticus Abou Awad and El-Bagoury, Table (1).The first species was found under onion soil in Qaluobia governorate while the second species were recorded in the soil of both Maize and faba bean in Giza and Qaluobia governorates, respectively. The two collected mite species were found in high numbers.

\section{Family: Erynetidae Oudemans}

Only one species of the family Erynetidae (Ereynetes sp.) was recorded, from Giza and Qaluobia governorate during this study from soil of cotton and broad bean, respectively in rare number.

\section{Family: Tydeidae Kramer}

Three mite species of the family Tydeidae were collected. These species were Orthotydeus kochi (Oudemans) from soil of broad bean in Qaluobia in high numbers, Tydeus aegyptiacus (Rasmy and El-Bagoury) from Menofia, Giza and Beni Suief governorates associated with soil of cotton and maize plants in moderate numbers and Pronematus rykei (Baker) from soil of onion in Qaluobia governorate in rare number.

\section{Family: Bdellidae Duges}

The bdellid mites, Spinibdella bifurcate Atyeo was collected from Giza in soil of maize plant in Giza and $S$. depressa Atyeo from soil of cotton and maize in Qaluobia governorate.

\section{Family: Cunaxidae Thor}

The following cunaxid mites, Cunaxa capreolus Berlese, C. setirostris (Hoffman), C.nercruzanum Baker and Hoffmann, Coleoscerius breslauensis (Den Heyer), Coleoscerius. baptos (Chaudhri), Neocunaxoides Andrei (Baker and Hoffman), Pulaeus zaheri EL-Bishlawy and Rakha and P.lebulentus, P. niloticus Zaher and ELBishlawy, P. glebulentus Den Heyer were collected associated with different soils planted with different filed crops, Table (1).The abundance of these individuals was also observed in Tables (1\&3).

\section{Family Raphignathidae Kramer}

Raphignathus niloticus Zaher, R..ehari Zaher and Gomaa and R..bakeri Zaher and Gomaa were collected from Qaluobia governorate associated with soil of maize, onion and maize plants, respectively. These mites were collected in moderate numbers.

\section{Family: Cheyletidae Leach}

The eleven cheyletid mites obtained during this study, Acaroppsellina docta (Berlese), A. notchi Gomaa and Hassan, Acaroppsellina sp., Cheletonella caucasica Volgin, Hemicheyletia congensis Volgin, Cheyletus badreyi Zaher and Hassan, C.eruditus (Shrank ), C. malaccensis Oudemans, Ker bakeri Zaher and Soliman, 
K.summersi Gomaa and Hassan and Eutogenes africanus Wafaa and Soliman were 11 different cheyletid species collected in this study inhabiting the soils of different field crops in different locations.

\section{Family Anystidae}

The family Anystidae was represented in this survey by one species Anystis sp. which collected in moderate number in soil cultivated with faba bean in Menofia governorate.

\section{Family Trombidiidae}

The predacous mite, Leeuwenhoekia sp. belongs to family Trombidiidae was recorded in the current study with rare number in Giza governorate associated with maize soil.

\section{Mites seasonal abundance in soil of tested field crops}

As shown in Table (2), the winter field crops were represented by 26 different soil predacous mites, where the broad bean harbored the highest number of mites (10 species), while onion, clover and wheat harbored 9, 3 and 4 soil mite species, respectively. On the other hand, the summer field crops harbored 31 mite species. The maize soil aggregated the high numbers of actinedid predacious mites (18 species) followed by cotton which harbored 8 different mite species, while soybean crop represented by the lowest, five mite species, Table (2).The most abundant mites were Cunaxa capreolus and C. setirostris (Family Cunaxidae) which associated with 3 and 4 soils of field crops, respectively, and the cheyletid mites Cheyletus eruditus and C. malaccensis which associated with four diferent soils of field crops, respectively, Table (2).Obtained results are in agree with those obtained by Zaher (1986), Kaid (1998), Romeih (2002) and Ezz El- Dein (2003), where the soil of the same filed crops harbored in most cases the actinedid mites as common soil mites in the Egyptian fauna. The abundance and presence of predacious mites might be related to growing plants, types of soil, organic matter, agrochemical applications and availability of prey as indicated in earlier studies (Al-Rehiayani and Fouly (2005), El-Benhawy, (2002) and El-Benhawy et al., (2006).

In conclusion, predaceous mites are free living arthropods mainly inhabiting different habitats. Food preference and specialization are not clear enough so far. The large number of predacous mites species found in the soil cultivated with different field crops may have a role in regulating insects, mites and nematode pests in these habitats. 
Table 1. Incidence of different soil actinedid predaceous mites inhabiting some field crops at different regions of Egypt.

\begin{tabular}{|c|c|c|c|c|}
\hline Family & Mites species & Locality & Host (s) & Abundance \\
\hline \multirow[t]{2}{*}{ Eupodidae Koch } & $\begin{array}{l}\text { Eupodes aegyptiacus } \\
\text { Abou Awad and El-Bagoury }\end{array}$ & Qaluobia & Onion, wheat & +++ \\
\hline & $\begin{array}{l}\text { Eupodes niloticus } \\
\text { Abou Awad and El-Bagoury }\end{array}$ & $\begin{array}{l}\text { Giza, } \\
\text { Qaluobia }\end{array}$ & $\begin{array}{l}\text { Maize, } \\
\text { Broad bean }\end{array}$ & +++ \\
\hline Erynetidae Oudemans & Ereynetes sp. & $\begin{array}{l}\text { Giza, } \\
\text { Qaluobia }\end{array}$ & $\begin{array}{l}\text { Cotton } \\
\text { Broad bean }\end{array}$ & $\begin{array}{l}+ \\
+ \\
\end{array}$ \\
\hline \multirow{3}{*}{ Tydeidae Kramer } & Orthotydeus kochi (Oudemans) & Qaluobia & Broad bean & +++ \\
\hline & $\begin{array}{l}\text { Tydeus aegyptiacus } \\
\text { (Rasmy and El-Bagoury) }\end{array}$ & $\begin{array}{l}\text { Menoufia, } \\
\text { Giza, } \\
\text { Beni Suief }\end{array}$ & Cotton, maize & ++ \\
\hline & Pronematus rykei (Baker) & $\begin{array}{l}\text { Qaluobia, } \\
\text { Menofia }\end{array}$ & Onion, clover & + \\
\hline \multirow[t]{2}{*}{ Bdellidae Duges } & Spinibdella bifurcate Atyeo & Giza, Menofia & Maize & ++ \\
\hline & Spinebdella depressa Atyeo & $\begin{array}{l}\text { Qaluobia, } \\
\text { Benha }\end{array}$ & $\begin{array}{l}\text { Cotton, } \\
\text { maize }\end{array}$ & ++ \\
\hline \multirow[t]{9}{*}{ Cunaxidae Thor } & Cunaxa capreolus Berlese & Qaluobia & $\begin{array}{l}\text { Maize, clover, } \\
\text { wheat, onion }\end{array}$ & ++ \\
\hline & Cunaxa setirostris (Hoffman ) & $\begin{array}{l}\text { El-Kanater, } \\
\text { Giza }\end{array}$ & $\begin{array}{l}\text { Maize, onion, } \\
\text { soybean, } \\
\text { cotton }\end{array}$ & + \\
\hline & $\begin{array}{l}\text { Cunaxa nercruzanum Baker } \\
\text { and Hoffmann }\end{array}$ & $\begin{array}{l}\text { Beni Suief, } \\
\text { Qaluobia }\end{array}$ & $\begin{array}{l}\text { Broad bean, } \\
\text { maize }\end{array}$ & $\begin{array}{l}+ \\
+\end{array}$ \\
\hline & $\begin{array}{l}\text { Coleoscerius breslauensis (Den } \\
\text { Heyer) }\end{array}$ & Qaluobia & Broad bean & + \\
\hline & Coleoscerius baptos (Chaudhri). & Qaluobia & Onion & + \\
\hline & $\begin{array}{l}\text { Neocunaxoides andrei } \\
\text { (Baker and Hoffman) }\end{array}$ & Giza, Menofia & Cotton, maize & +++ \\
\hline & $\begin{array}{l}\text { Pulaeus zaheri EL-Bishlawy } \\
\text { and Rakha }\end{array}$ & Qaluobia & Broadbean & + \\
\hline & $\begin{array}{l}\text { Pulaeus niloticus Zaher and } \\
\text { EL-Bishlawy }\end{array}$ & Giza & $\begin{array}{l}\text { Cotton, } \\
\text { soybean }\end{array}$ & + \\
\hline & Pulaeus glebulentus Den Heyer & $\begin{array}{l}\text { Giza, } \\
\text { Qaluobia }\end{array}$ & Cotton, maize & $\begin{array}{l}++ \\
++\end{array}$ \\
\hline \multirow[t]{2}{*}{ Raphignathidae Kramer } & Raphignathus niloticus Zaher & $\begin{array}{l}\text { Qaluobia, } \\
\text { Menofia }\end{array}$ & $\begin{array}{l}\text { Maize, } \\
\text { soybean }\end{array}$ & ++ \\
\hline & $\begin{array}{l}\text { Raphignathus ehari Zaher } \\
\text { and Gomaa }\end{array}$ & Qaluobia & Onion & ++ \\
\hline
\end{tabular}


Table 1. Cont.,

\begin{tabular}{|c|c|c|c|c|}
\hline Family & Mites species & Locality & Host (s) & Abundance \\
\hline Raphignathidae Kramer & $\begin{array}{l}\text { Raphignathus bakeri } \\
\text { Zaher and Gomaa }\end{array}$ & Qaluobia & Maize & ++ \\
\hline \multirow{11}{*}{ Cheyletidae Leach } & $\begin{array}{l}\text { Acaroppsellina docta } \\
\text { (Berlese) }\end{array}$ & Qaluobia & Cotton & + \\
\hline & $\begin{array}{l}\text { Acaroppsellina notchi } \\
\text { Gomaa and Hassan }\end{array}$ & Qaluobia, & Cotton, Maize & ++ \\
\hline & Acaroppsellina sp. & Qaluobia & Onion & + \\
\hline & $\begin{array}{l}\text { Cheletonella caucasica } \\
\text { Volgin }\end{array}$ & Qaluobia & Maize, wheat & +++ \\
\hline & $\begin{array}{l}\text { Henicheyletia congensis } \\
\text { Volgin }\end{array}$ & $\begin{array}{l}\text { Menofia, } \\
\text { Giza }\end{array}$ & Maize, onion & ++ \\
\hline & $\begin{array}{l}\text { Cheyletus badreyi Zaher } \\
\text { and Hassan }\end{array}$ & Qaluobia & $\begin{array}{l}\text { Maize, } \\
\text { soybean }\end{array}$ & + \\
\hline & $\begin{array}{l}\text { Cheyletus eruditus } \\
\text { (Shrank ) }\end{array}$ & Giza & $\begin{array}{l}\text { Onion, clover, } \\
\text { Maize, } \\
\text { soybean }\end{array}$ & +++ \\
\hline & $\begin{array}{l}\text { Cheyletus malaccensis } \\
\text { Oudemans }\end{array}$ & $\begin{array}{l}\text { Giza, } \\
\text { Qaluobia, } \\
\text { Beni Suief }\end{array}$ & $\begin{array}{l}\text { Onion, Clover, } \\
\text { cotton, Wheat }\end{array}$ & +++ \\
\hline & $\begin{array}{l}\text { Ker bakeri Zaher and } \\
\text { Soliman }\end{array}$ & Qaluobia & $\begin{array}{l}\text { Broad bean, } \\
\text { soybean }\end{array}$ & + \\
\hline & $\begin{array}{l}\text { Ker summersi Gomaa } \\
\text { and Hassan }\end{array}$ & Qaluobia & $\begin{array}{l}\text { Broad bean, } \\
\text { wheat }\end{array}$ & + \\
\hline & $\begin{array}{l}\text { Eutogenes africanus } \\
\text { Wafaa and Soliman }\end{array}$ & $\begin{array}{l}\text { Menofia, } \\
\text { Qaluobia }\end{array}$ & $\begin{array}{l}\text { Maize, Broad } \\
\text { bean }\end{array}$ & $\begin{array}{l}+ \\
+ \\
\end{array}$ \\
\hline Anystidae Oudemans & Anystes sp. & Menofia & $\begin{array}{l}\text { Broad bean, } \\
\text { soybean }\end{array}$ & ++ \\
\hline Trombidiidae & Leeuwenhoekia sp. & Giza & Maize, wheat & + \\
\hline
\end{tabular}

$+=$ rare number $<3$ individuals.

$++=$ moderate number (3-9) individuals.

$+++=$ high number (more than 9 individuals). 
Table 2. Prescence of different soil actinedid predacous mites associated with different field crops

\begin{tabular}{|c|c|c|c|c|c|c|c|c|}
\hline \multirow{2}{*}{ Family } & \multirow{2}{*}{ Species } & \multicolumn{4}{|c|}{ Winter field crops } & \multicolumn{3}{|c|}{ Summer field crops } \\
\hline & & Onion & Faba bean & Clover & Wheat & Cotton & Maize & Soybean \\
\hline \multirow{2}{*}{ Eupodidae } & Eupodes aegyptiacus & + & - & - & + & - & - & - \\
\hline & Eupodes niloticus & - & + & - & - & - & + & - \\
\hline Ereynetidae & Ereynetes sp. & - & + & - & - & + & - & - \\
\hline \multirow{3}{*}{ Tydeidae } & Orthotydeus kochi & - & + & - & - & - & - & - \\
\hline & Tydeus aegyptiacus & - & - & - & - & + & + & - \\
\hline & Pronematus rykei & + & - & + & - & - & - & - \\
\hline \multirow{2}{*}{ Bdellidae } & Spinibdella bifurcate & - & - & - & - & - & + & - \\
\hline & Spinebdella depressa & - & - & - & - & + & + & - \\
\hline \multirow{9}{*}{ Cunaxidae } & Cunaxa capreolus & + & - & - & + & - & + & - \\
\hline & Cunaxa setirostris & + & - & - & - & + & + & + \\
\hline & Cunaxa nercruzanum & - & + & - & - & - & + & - \\
\hline & Coleoscerius breslauensis & - & + & - & - & - & - & - \\
\hline & Coleoscerius baptos & + & - & - & - & - & - & - \\
\hline & Neocunaxoides andrei & - & - & - & - & + & + & - \\
\hline & Pulaeus zaheri & - & + & - & - & - & - & - \\
\hline & Pulaeus niloticus & - & - & - & - & - & + & + \\
\hline & Pulaeus glebulentus & - & - & - & - & + & + & - \\
\hline \multirow{3}{*}{ Raphignathidae } & Raphignathus niloticus & & & & & & + & + \\
\hline & Raphignathus ehari & + & - & - & - & - & - & - \\
\hline & Raphignathus bakeri & - & - & - & - & - & + & - \\
\hline
\end{tabular}


Table 2. Cont.

\begin{tabular}{|c|c|c|c|c|c|c|c|c|}
\hline \multirow[t]{2}{*}{ Family } & \multirow[t]{2}{*}{ Species } & \multicolumn{4}{|c|}{ Winter field crops } & \multicolumn{3}{|c|}{ Summer field crops } \\
\hline & & Onion & Broad bean & Clover & Wheat & Cotton & Maize & Soybean \\
\hline \multirow[t]{11}{*}{ Cheyletidae } & Acaroppsellina docta & - & - & - & - & + & - & - \\
\hline & Acaroppsellina notchi & - & - & - & - & + & + & - \\
\hline & Acaroppsellina sp. & + & - & - & + & - & + & - \\
\hline & Cheletonella caucasica & - & - & - & - & - & - & - \\
\hline & Henicheyletia congensis & + & - & - & - & - & + & - \\
\hline & Cheyletus badreyi & - & - & - & - & - & + & + \\
\hline & Cheyletus eruditus & + & - & + & - & - & + & + \\
\hline & Cheyletus malaccensis & + & - & + & + & + & - & - \\
\hline & Ker bakeri & - & + & - & - & - & - & + \\
\hline & Ker summersi & - & + & - & + & - & - & - \\
\hline & Eutogenes africanus & - & + & - & - & - & + & - \\
\hline Anystidae & Anystes sp. & - & + & - & - & - & - & + \\
\hline Trombididae & Leeuwenhoekia sp. & - & - & - & + & - & + & - \\
\hline
\end{tabular}

$+=$ prescence

- = absent 


\section{REFERENCES}

1. Al-Rehiayani, S.M. and A.H. Fouly, 2005. Cosmolaelaps simplex (Berlese), a polyphagous predatory mite feeding on root-knot nematode Meloidogyne javanica and citrus nematode Tylenchulus semipenetrans. Pakistan J. Biol. Sci., 8: 168-174

2. Convey P., P. Greenslade and P. J. Pugh 2000. The terrestrial microarthropod fauna of the South Sandwich Islands. J. Nat. His., 34:597-609

3. El-Benhawy, S. M. 2002. Survey of predatory mites in the kingdom of Lesotho (Africa): Notes on altitudinal preference of predatory mites and description of a new species (Acari: Phytoseiidae). Int. J. Acarol., 28: 187-191.

4. El-Benhawy, S.M., A. K. Nasr and S.I. Afia, 2006. Survey of predaceous soil mites (Acari: Mesostigmata) in citrus orchards of the Nile Delta and Middle Egypt with notes on the abundance of the citrus parasitic nematode Tylenchulus semipenetrans (Tylenchida: Tylenchulidae). Int. J. Tropical Insect Sci., 26: 64-69.

5. Evans, G. O. 1992. Principles of Acarology. C. A. B. International, Wallingford, $563 \mathrm{pp}$.

6. Ezz El-Dein. S. A. 2003. Studies on some soil predacous mites associated with some field crops. M. Sc. Thesis, Fac. Sci., Al-Azhar Univ., (Girls), 148 pp.

7. Griffiths, D. A. 1960 . Some field habitats of mites of stored food products. Ann. Appl. Biol., 49: $134-144$

8. Hughes, A. M. 1976. The mites of stored food products and houses. Tech. Bull., Min. Agric. And Fisheries in London, 63: 105 - 110.

9. Kaid, N. A. O. 1998. Ecological and biological studies on some soil predacous mites. M. Sc. Thesis, Fac. Agric., Al-Azhar Univ., pp. 66.

10. Krantz, G.W. and D. E. Walter (eds.) 2009. A Manual of Acarology. Texas Tech Univ. Press, $807 \mathrm{pp}$.

11. Mostafa, A. M. 1980. Effect of direct and indirect contamination of soil by some pesticides on the population density of soil mites in cotton fields. M.Sc.Thesis, Fac. Agric., Ain Shams Univ.,141 pp.

12. Romeih, A. H. M. 2002. Biological, morphological and genetical studies on some predacous mites and their prey. Ph. D. Thesis, Fac. Agric., Cairo Univ., 208 pp.

13. Summers, F. M. and D. W. Price 1970 . Review of the mite family Cheyletidae. Univ. California Publ. Entomol. : 61 -153.

14. Volgin, V. I. (eds.) 1989. Acarina of family Cheyletidae of the world. Leiden New York. Kobenltvan Koln., 531 pp.

15. Wallwork, J. A. 1976. The distribution and diversity of soil fauna. London: Academic Press, pp 335.

16. Zaher, M. A. 1986. Survey and ecological studies on phytophagous, predaceous and soil mites in Egypt. II- Predaceous and non-phytophagus mites.EG. Ars-30, Grant No. F. G. E. G., 567 pp. 


\section{تواجد الاكاروسات المفترسة ذات الثغر الامامى المرتبطة بتربة بعض المحاصيل

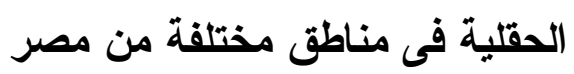

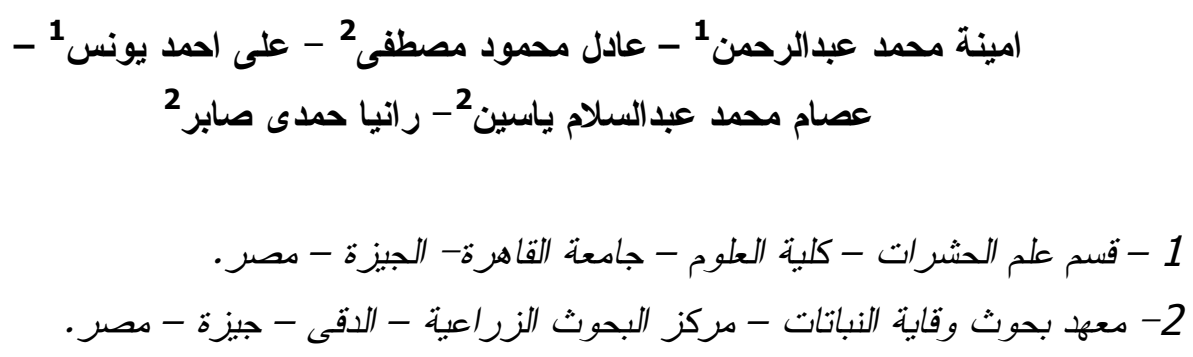

اجريت هذه الدراسة لحصر الاكاروسات المفترسة المنتمية الى تحت رتبة ذات الثغر الامــىى و المرتبطة بتربة بعض المحاصيل الحقلية (الفول البلدى - البصل - القمح - البرســيم ) كمحاصـيل

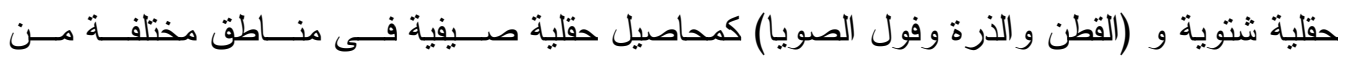

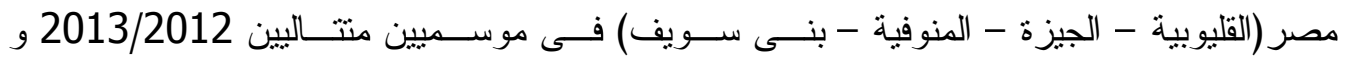
2014/2013 وقد اسفرت الدر اسة على وجود 33 نوع من المفترســات الاكاروســية تابعــة ل 9

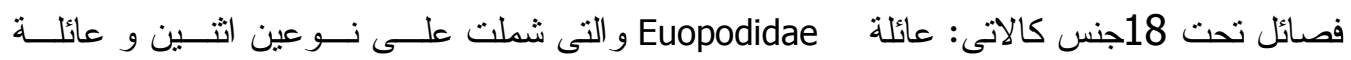

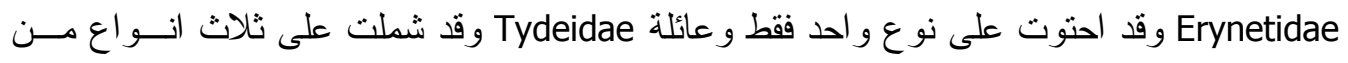

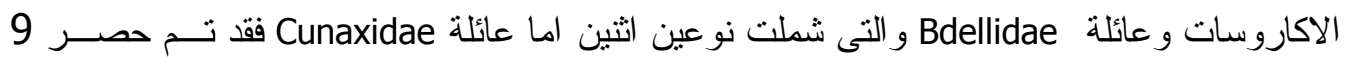

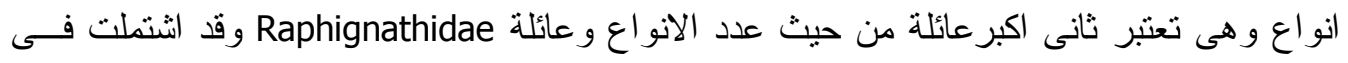

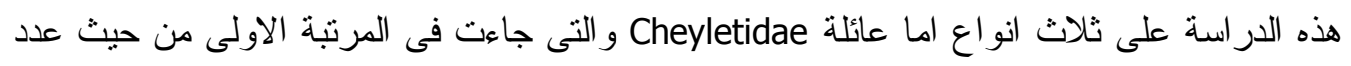

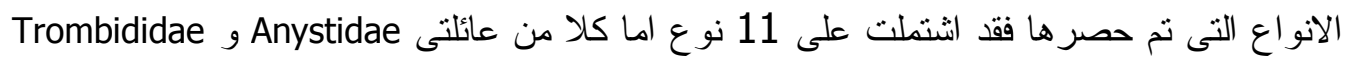
فقد احتوت كلا منهما على نوع و احد فقط فى هذه الدراسة. ولقد وجد ان المحاصيل الثنتوية فى هذه

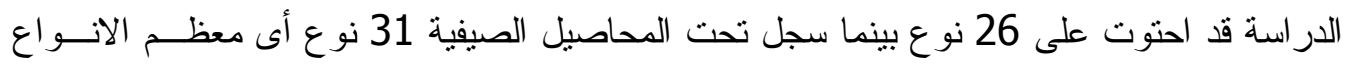

